\title{
Leptin inhibits insulin-stimulated incorporation of glucose into lipids and stimulates glucose decarboxylation in isolated rat adipocytes
}

\author{
RB Ceddia1, WN William Jr², FB Lima² and Curi $\mathbf{R}^{2}$
}

${ }^{1}$ Department of Physical Education - Fluminense Federal University, UFF, Rio de Janeiro - Brazil, ${ }^{2}$ Department of Physiology and Biophysics, Av. Prof. Lineu Prestes, 1524, University of São Paulo, USP, 05508900 - Brazil.

(Requests for offprints should be addressed to R Curi)

\begin{abstract}
Leptin is an adipocyte hormone involved in the regulation of energy homeostasis. Generally accepted biological effects of leptin are inhibition of food intake and stimulation of metabolic rate in $o b / o b$ mice, that are defective in the leptin gene. In contrast to these centrally mediated effects of leptin, we are reporting here on leptin effects on glucose incorporation into lipids and glucose decarboxylation in adipocytes isolated from male lean albino rats. Adipocytes previously cultivated $(15 \mathrm{~h})$ in the presence of leptin presented a $25 \% \quad(P<0.05) \quad$ reduction of the insulin stimulated incorporation of glucose into lipids. Concurrently, the basal conversion of $\left(\mathrm{U}_{-}{ }^{14} \mathrm{C}\right) \mathrm{D}$-glucose into ${ }^{14} \mathrm{CO}_{2}$ increased $(110 \%)$
\end{abstract}

\section{Introduction}

The ob gene product, leptin, is produced in adipose tissue. In ob/ob mice, a mutation in the ob gene prevents normal leptin production and results in obesity and diabetes. Daily injections of recombinant leptin inhibit food intake and reduce body weight and fat mass in ob/ob mice (Campfield et al 1995, Halaas et al. 1995), and normalize glycemia (Halaas et al. 1995, Pelleymounter et al. 1995). It has also been observed that changes in glycemia precede changes in body weight (Pelleymounter et al. 1995). Additionally, pair-feeding studies (Levin et al. 1996) and experimental hyperleptinemic animal models (Unger 1997) provide compelling evidence that leptin exerts adipose-reducing effects in excess of those induced by decreases in food intake, suggesting a significant metabolic regulation role for leptin, in addition to appetite suppression. It has been recently reported that leptin stimulates glucose transport and glycogen synthesis in $\mathrm{C}_{2} \mathrm{C}_{12}$ myotubes (Berti et al. 1997) in opposition to previous findings that leptin impairs insulin signaling, i.e. insulin receptor autophosphorylation and insulin-receptor substrate (IRS)-1 phosphorylation in rat-1 fibroblasts, NIH3T3 cells (Kroder et al. 1996) and HepG2 cells (Cohen et al. 1996).

Since the identification of the $\mathrm{Ob}$ protein receptor in adipocytes (Hoggard et al. 1997), it has been speculated that leptin may also exert an autocrine effect. However, very few data are available regarding this issue. Recently, it was demonstrated that in isolated rat adipocytes leptin per se increases glucose uptake in adipocytes but impairs the in the leptin cultivated adipocytes and reached values (1.54 $\mathrm{nmol} / 10^{5}$ cells) similar to the insulin stimulated group (not cultivated with leptin) $\left(1.40 \mathrm{nmol} / 10^{5}\right.$ cells $)$. In addition, in the presence of insulin, the leptin cultivated adipocytes elicited a $162 \%(P<0.05)$ increase in ${ }^{14} \mathrm{CO}_{2}$ production that was significantly higher than the increase observed for the notleptin-cultivated insulin group (92\%). We conclude that leptin: 1) directly inhibits the insulin stimulated glucose incorporation into lipids; 2) stimulates glucose decarboxylation, and also potentiates the effect of insulin on glucose decarboxylation in isolated adipocytes. Leptin per se does not alter glucose incorporation into lipids. metabolic effects of insulin (Muiller et al. 1997). According to Walder et al. (1997) the binding of insulin to its receptors is inhibited by leptin. In order to test whether leptin is able to directly alter glucose metabolism in adipocytes, $\left(\mathrm{U}-{ }^{14} \mathrm{C}\right) \mathrm{D}$ glucose incorporation into lipids and the conversion of $(\mathbf{U}$ ${ }^{14} \mathrm{C}$ ) D-glucose into ${ }^{14} \mathrm{CO}_{2}$ were measured in incubated rat adipocytes. The effect of leptin on glucose metabolism was evaluated either in the presence or absence of insulin.

\section{Materials and Methods}

\section{Experimental animals}

Male albino rats (Wistar strain), weighing 140-160 g were maintained on a 12-12 h light-dark cycle at $22^{\circ} \mathrm{C}$ and fed ( $a d$ libitum) a standard laboratory chow. Ethics approval was granted for these studies by the Institute of Biomedical Sciences, Animal Experimental Committee, University of São Paulo.

\section{Primary culture of adipocytes and washing procedures}

Adipocytes were isolated as previously described (Lima \& Garvey 1991). Briefly, rats were killed by cervical dislocation, and epididymal fat pads removed under sterile conditions. Isolated cells were obtained by shaking ( 150 orbitals $/ \mathrm{min}$ ) finely minced tissue $(2-4 \mathrm{~g})$ in 4-oz. sterile polypropylene containers at $37^{\circ} \mathrm{C}$ for $45 \mathrm{~min}$ in Dulbecco's MEM (10 ml) containing $25 \mathrm{mM}$ Hepes, collagenase $(1 \mathrm{mg} / \mathrm{ml})$, and albumin (40 $\mathrm{mg} / \mathrm{ml}$ ). Cells were then washed in Dullbecco's MEM 
containing $20 \mathrm{mM}$ Hepes, $2 \%$ fetal calf serum, and $1 \%$ bovine serum albumin, and filtered through nylon mesh. All Dullbecco's MEM buffers contained 5.6 mM D-glucose, and were added with penicillin $(20 \mathrm{U} / \mathrm{ml})$ and streptomycin $(20$ $\mathrm{mg} / \mathrm{ml}$ ). Adipocyte number was determined according to a previously described method (Lima \& Garvey 1991). Isolated adipocytes $\left(5 \times 10^{4}\right.$ cells $\left./ \mathrm{ml}\right)$ were then placed in air tight, $50 \mathrm{ml}$ sterile polypropylene tubes with cells floating on top of the medium in a thin cell layer, and were maintained in primary culture at $37^{\circ} \mathrm{C}$ for $15 \mathrm{~h}$ either in the presence or absence of murine leptin (10 ng/ml) [Amgem Inc., Thousand Oaks, California, USA].

Incorporation of $\left(U^{14} C\right) D$-glucose into lipids and conversion of $\left(U_{-}{ }^{14} \mathrm{C}\right) \mathrm{D}$-glucose into ${ }^{14} \mathrm{CO}_{2}$

Incorporation of $\left(\mathrm{U}^{-14} \mathrm{C}\right) \mathrm{D}$-glucose into lipids and the conversion of $\left(\mathrm{U}-{ }^{14} \mathrm{C}\right) \mathrm{D}$-glucose into ${ }^{14} \mathrm{CO}_{2}$ were determined using the methods described by Lima et al. (1994) and Rodbell (1964). Briefly, the adipocytes were washed three times and resuspended to $5 \%$ lipocrit. One $\mathrm{ml}$ of the cell suspension was incubated for $1 \mathrm{~h}\left(37^{\circ} \mathrm{C}\right.$ with shaking) in a 20-ml plastic scintillation flasks which had a centered-isolated well containing a loosely folded piece of filter paper moistened with $0.2 \mathrm{ml}$ of 2-phenylethylamine/methanol $(1: 1, \mathrm{v} / \mathrm{v})$. The incubation medium contained $0.2 \mu \mathrm{Ci} / \mathrm{ml}$ of $\left(\mathrm{U}-{ }^{14} \mathrm{C}\right) \mathrm{D}$-glucose, $5.6 \mathrm{mM}$ of $\mathrm{D}$-glucose in the presence or absence of insulin $(10000 \mu \mathrm{U} / \mathrm{ml})$. After the 1-hour incubation period the medium was acidified with $0.3 \mathrm{ml}$ of $\mathrm{H}_{2} \mathrm{SO}_{4}(8 \mathrm{~N})$ and the flasks incubated for a further $60 \mathrm{~min}$ period. At the end of the incubation, the filter paper was transferred into scintillation vials for measurement of radioactivity and the reaction mixture was treated with $5 \mathrm{ml}$ Dole's reagent (isopropanol:n-heptane: $\mathrm{H}_{2} \mathrm{SO}_{4}, 4: 1: 0.25$, v/v/v) for lipid extraction (Dole \& Meinertz 1960).

\section{Statistical analysis}

All data are expressed as the mean \pm S.E.M. Statistical analysis was performed by one-way analysis of variance (ANOVA) with Tukey-Kramer multiple comparison test. The level of significance was set at $P<0.05$.

\section{Results and Discussion}

Adipocytes cultivated $(15 \mathrm{~h})$ in the presence of $10 \mathrm{ng} / \mathrm{ml}$ of leptin did not elicit a significant alteration on basal $\left(\mathrm{U}-{ }^{14} \mathrm{C}\right) \mathrm{D}$ glucose incorporation into lipids compared to control. However, when these adipocytes were stimulated by insulin, a significant reduction $(25 \%)$ of the incorporation of $\left(\mathrm{U}-{ }^{14} \mathrm{C}\right) \mathrm{D}$ glucose into lipids (Figure 1) was observed. Concurrently, the basal conversion of $\left(\mathrm{U}_{-}{ }^{14} \mathrm{C}\right) \mathrm{D}$-glucose into ${ }^{14} \mathrm{CO}_{2}$ increased $(110 \%)$ in the leptin cultivated adipocytes and reached values (1.54 nmol $/ 10^{5}$ cells) similar to the insulin stimulated group (not cultivated with leptin) $\left(1.40 \mathrm{nmol} / 10^{5}\right.$ cells $)$. In addition, the leptin cultivated adipocytes when in the presence of insulin

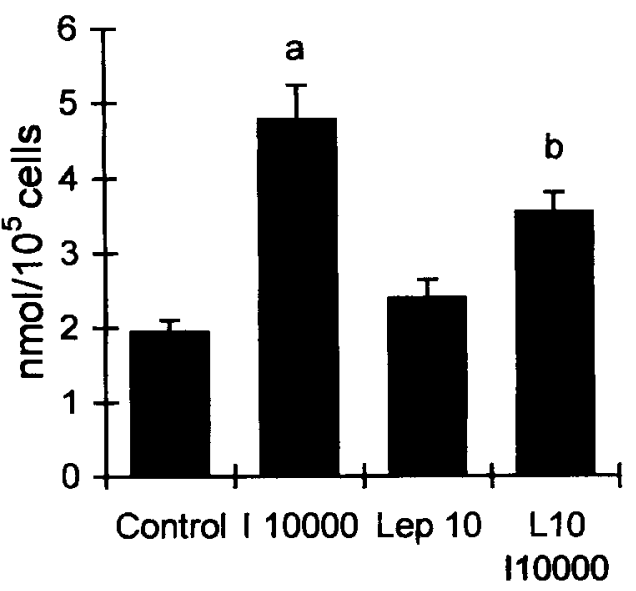

Figure 1 Incorporation of $\left(\mathrm{U}-{ }^{14} \mathrm{C}\right) \mathrm{D}$-glucose into lipids ( $\mathrm{nmol} / 10^{5} \mathrm{cells}$ ) in adipocytes cultivated $(15 \mathrm{~h})$ in the presence and absence of leptin. Control = no insulin / no leptin; I10000 = Insulin stimulated $(10000 \mu \mathrm{U} / \mathrm{ml})$; Lep $10=$ Leptin cultivated $(10 \mathrm{ng} / \mathrm{ml}) ;$ L10 $110000=$ Leptin cultivated $(10 \mathrm{ng} / \mathrm{ml})+$ Insulin stimulated $(10000 \mu \mathrm{U} / \mathrm{ml})$. ${ }^{a} P<0.05$ vs control and Lep $10 ;{ }^{b} P<0.05$ vs control, 110000 and Lep10; $n=14$.

elicited an increase of $162 \%(P<0.05)$ in ${ }^{14} \mathrm{CO}_{2}$ production, that was significantly higher than the increase observed for the insulin stimulated adipocytes [not cultivated with leptin] (92 \%) [Figure 2].

A recent publication described that long-term cultivation of isolated adipocytes in the presence of leptin results in impairment of insulin action on metabolic processes including glucose transport, glycogen synthesis and lipogenesis (Müller et al. 1997).

According to our results, leptin seems to shift the adipocyte metabolism, reducing the synthesis of lipids from glucose, and increasing the oxidation rate of this metabolite that could otherwise be stored as fat in adipose tissue. These results are also consistent with recently in vivo published data from Sarmiento et al. (1997) and Zhou et al. (1997) who have reported that hyperleptinemia up-regulates UCP-2 expression in fat tissue (epididymal, retroperitoneal, and subcutaneous). In fact, the expression of UCP-2 was increased up to 2-fold in adipose tissue (white and brown) of leptin treated mice (Sarmiento et al. 1997), and the lipid content of the fat cells was dramatically reduced, reaching non detectable values. These in vivo studies provide evidence that leptin exerts a powerful adipose reducing effect, however they do not clarify if it is a result of a direct or a CNS-mediated effect of leptin. In the present study, we provide evidence that leptin is capable of directly interfering with adipocyte metabolism. In addition to isolated adipocytes (Walder et al 1997, Müller et al. 1997), direct effects of leptin on glucose and lipid metabolism have also already been reported on $\mathrm{C}_{2} \mathrm{C}_{12}$ myotubes (Berti et al. 1997), and skeletal muscle (Muoio et al. 1997, Liu et al. 1997). 


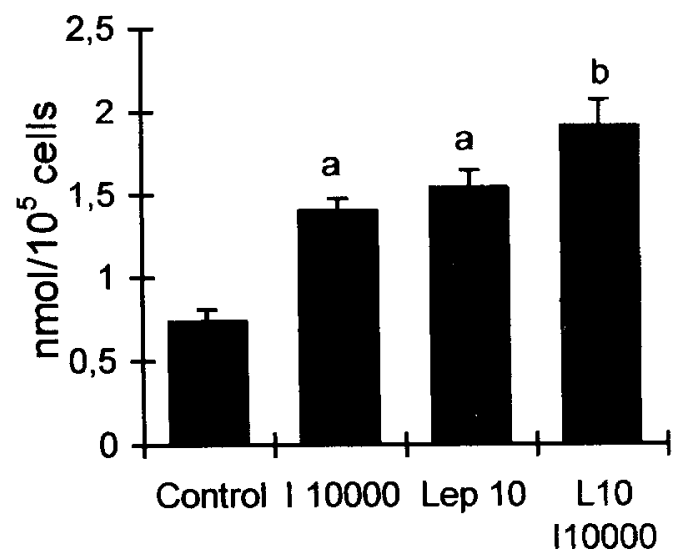

Figure 2 Incorporation of $\left(\mathrm{U}-{ }^{14} \mathrm{C}\right) \mathrm{D}$-glucose into ${ }^{14} \mathrm{CO}_{2}$ (nmol/10 $10^{5}$ cells) in adipocytes cultivated (15h) in the presence and absence of leptin. Control = no insulin / no leptin; $110000=$ Insulin stimulated $(10000 \mu \mathrm{U} / \mathrm{ml})$; Lep $10=$ Leptin cultivated $(10 \mathrm{ng} / \mathrm{ml}) ; \mathrm{L} 10 \mathrm{I} 10000=$ Leptin cultivated $(10 \mathrm{ng} / \mathrm{ml})$ and Insulin stimulated $(10000 \mu \mathrm{U} / \mathrm{ml})$. ${ }^{\text {a }} \mathrm{P}<0.05$ vs control; ${ }^{b} \mathrm{P}<0.05$ vs control and $110000 ; n=14$

These findings indicate that, as a hormone, leptin may exert multiple effects in different peripheral tissues, independently of signaling to the CNS.

In non obese humans, plasma leptin values lie between 1 and $20 \mathrm{ng} / \mathrm{ml}$ (Bauman et al. 1996). The concentration of leptin applied in our experiments $(10 \mathrm{ng} / \mathrm{ml})$ is within the physiological range. It indicates that, at least in adipose tissue, it is not necessary supra-physiological concentrations to observe direct effects of leptin.

Taken as a whole, these data led us to suggest that leptin exerts an autocrine effect as an anti obesity hormone controlling the amount of energy stored in adipocytes (Ceddia et al. 1998). Further studies are necessary to clarify the relationship between obesity and reduced insulin sensitivity and the role of leptin in the development of NIDDM in obese subjects.

\section{Acknowledgments}

The authors are indebted to the technical assistance of $\mathbf{J} \mathbf{R}$. Mendonca, G de Souza and CK Miyasaka. We would like to thank Amgem Inc., Thousand Oaks, California, for kindly supplying leptin. This study was supported by FAPESP, CNPq, CAPES and PRONEX (168/97).

\section{References}

Bauman WA, Spungen AM, Zhong YG, Mobbs CV 1996 Hormone and Metabolic Research 28 732-736.

Berti L, Kellerer M, Capp E \& Haring HU 1997 Diabetologia 40 606609.

Campfield LA, Smith FJ, Guisez Y, Devos R \& Burn P 1995 Science 269 546-549.

Ceddia RB, William Jr WN, Lima FB, Carpinelli AR \& Curi R 1998 Brazilian Journal of Medical and Biological Research 31 715722.

Cohen B, Novick D \& Rubinstein M 1996 Science 274 1185-1188.

Dole VP \& Meinertz H 1960. Journal of Biological Chemistry 235 2595-2599.

Halaas JL, Gajiwala KS, Maffei M, Cohen SL, Chait BT, Rabinowitz D, Lallone RL, Burley SK \& Friedmam JM 1995 Science 269543546.

Hoggard N, Mercer JG, Rayner DV, Moar K, Trayhurn P \& Williams LM 1997 Biochemical and Biophysical Research Communications 232 383-387.

Kroder G, Kellerer M \& Haring HU 1997.Experimental and Clinical Endocrinology and Diabetes 10466.

Levin N, Nelson C, Gurney A, Vandlen R \& De Sauvage F 1996 Proceedings of the National Academy of Sciences of the USA 93 1726-1730.

Lima FB, Bao S \& Garvey WT 1994 Diabetes 43 53-62.

Liu YL, Emilsson V\& Cawthorne MA FEBS Lett 411 351-355.

Muoio DM, Dohn GL, Fiedorek FT Jr, Tapscott EB \& Coleman RA 1997 Diabetes 46 1360-1363.

Müller G, Ertl J, Gerl M \& Preibish G 1997 Journal of Biological Chemistry 272 10585-10593.

Pelleymounter MA, Cullen MJ, Baker MB, Hecht R, Winter D, Boone T \& Collins F 1995 Science 269 540-543.

Rodbell M 1964 Journal of Biological Chemistry 239 375-380.

Sarmiento U, Benson B, Kaufman S, Ross L, Qi M, Scully S \& DiPalma C 1997 Laboratory Investigation 77 243-256.

Unger RH 1997 Trends in Endocrinology and Metabolism 8 276-282.

Walder K, Filippis A, Clark S, Zimmet P \& Collier GR 1997 Journal of Endocrinology 155 R5-R7.

Zhou YT, Shimabukuro M, Koyama K, Lee Y, Wang MY, Trieu F,

Newgard CB \& Unger RH 1997 Proceedings of the National Academy of Sciences of the USA 94 6386-6390. 